Tersedia Online: http://journal.unj.ac.id/unj/index.php/jpensil

\title{
PENGEMBANGAN MEDIA PEMBELAJARAN E-LEARNING BERBASIS MOODLE PADA MATA KULIAH METODOLOGI PENELITIAN
}

\section{(Studi pada Program Studi Pendidikan Teknik Bangunan, Fakultas Teknik, Universitas Negeri Jakarta)}

\author{
Hamdi Mubammad Khoir, ${ }^{1}$ R. Eka Murtinugraha' ${ }^{2}$, Sittati Musalamah ${ }^{3}$ \\ ${ }^{1,2}$ Universitas Negeri Jakarta \\ 1'hmkhoir14@gmail.com ${ }^{2}$ r ekomn@yahoo.com,${ }^{3}$ smusalamah@uni.ac.id \\ Diterima : 27 Desember 2019 \\ Direvisi : 29 Januari 2020 \\ Diterbitkan : 30 Januari 2020 \\ DOI $\quad: 10.21009 /$ ipensil.v9i1.13453
}

\begin{abstract}
The aim of this research is to produce Moodle-based E-Learning learning media in the Research Methodology course with the help of Power Point Software, Google Slides and Moodle. This research is a type of Research and Development research using the 4D development model (Define, Design, Development and Dissemination). This study uses a non-test instrument data collection technique that is a questionnaire given to 2 material experts and 2 media experts. The results of the feasibility of learning media products, amounting to 11 learning materials using a Likert scale in the form of a score of 1-5 are as follows: a) The validation results by the material experts obtained a score of $81.54 \%$ which is included in the very feasible category; b) Results validation by media experts obtained a score of $78.4 \%$ which is included in the feasible category. Based on the results of the feasibility, it can be concluded that the learning media of E-Learning Moodle is appropriate to be used.
\end{abstract}

Keywords: E-Learning, Moodle, Research Methodology

\section{Pendahuluan}

Dalam menghadapi era revolusi industri 4.0. tentunya tidak asing lagi dengan perkembangan teknologi yang semakin pesat. Hal itu juga mengakibatkan semakin pesatnya perkembangan teknologi di dunia Pendidikan Indonesia. Dengan semakin pesatnya kemajuan teknologi tersebut, tentunya mendorong para pendidik untuk terus memperbaharui media pembelajaran yang digunakan dalam mentransfer ilmu kepada peserta didik. Di samping itu, pendidik juga di tuntut untuk dapat menguasai dan memanfaatkan kemajuan teknologi yang ada agar terciptanya peserta didik yang prestatif serta dapat belajar secara mandiri dan kreatif.
Prestasi belajar sering kali dikaitkan dengan beberapa permasalahan belajar yang dialami oleh peserta didik, diantaranya karena faktor belajar siswa yang kurang efektif, bisa juga karena materi atau media pembelajaran yang disampaikan dengan cara yang kurang menarik. Sistem pembelajaran yang konvensional erat kaitannya dengan suasana pembelajaran yang instruksional dianggap kurang tepat apabila disesuaikan dengan kemajuan ilmu pengetahuan serta teknologi yang begitu pesat. Sistem pembelajaran konvensional, kurang efektif dan belum dapat mengikuti perkembangan zaman karena pendidik sebaiknya dapat menyesuaikan materi dan media pembelajaran sesuai dengan kemajuan teknologi terkini (Sodikin, 2009: 740). 
Kata media berasal dari Bahasa Latin, yaitu medius yang artinya tengah, perantara atau pengantar. Dalam Bahasa Arab, media artinya perantara atau pengantar pesan dari pengirim kepada penerima (Arsyad,2016). Association for Education and Communication Tecnologi (AECT) di Amerika, membatasi media sebagai segala bentuk dan sarana yang digunakan manusia untuk menyampaikan pesan/informasi (Sadiman, 2009: 6). Media adalah sebuah alat yang dapat digunakan untuk menyalurkan pesan dari pengirim ke penerima sehingga dapat merangsang fikiran, perasaan, perhatian, dan minat serta perhatian peserta didik sedemikian hingga terjadilah proses pembelajaran (Sardiman, 2010: 3). Hal tersebut dapat dipahami bahwa, media adalah sebuah alat bantu yang dijadikan sebagai penyalur pesan untuk mencapai sebuah tujuan pembelajaran (Komsiah, 2012: 73). Sejumlah kontribusi media dalam kegiatan pembelajaran yang diantaranya : penyajian materi agar menjadi lebih standar, kegiatan pembelajaran dapat berjalan lebih menarik, kegiatan pembelajaran dapat menjadi lebih interaktif, waktu yang dibutuhkan dalam pembelajaran dapat digunakan secara efisien, kualitas belajar dapat ditingkatkan, pembelajaran dapat disajikan dimana dan kapan saja, meningkatkan sifat positif perserta didik dan proses belajar dapat menjadi lebih baik, dan memberikan nilai positif untuk pengajar. Media pembelajaran juga berkaitan erat dengan kemajuan teknologi sebagai alat proses pembelajaran untuk mencapai suatu tujuan pembelajaran. Proses Belajar ( Learning ) dengan memanfaatkan media atau bantuan alat elektronik diharapkan dapat meningkatkan efektifitas dan efisiensi dari kegiatan pembelajaran. (Uno, 2011: 124)

Dari beberapa pendapat para ahli diatas, dapat disimpulkan bahwa media adalah sebuah sarana yang dapat digunakan sebagai perantara dari pendidik kepada peserta didik untuk mencapai tujuan pembelajaran yang ditetapkan.
Dalam berjalannya sebuah proses pembelajaran, kehadiran media memiliki arti yang cukup penting. Ketidakjelasan bahan atau materi yang akan disampaikan dalam proses pembelajaran akan dapat dibantu dengan hadirnya media sebagai perantaranya. Dengan kata lain, media pembelajaran berfungsi sebagai sarana yang dapat memberikan pengalaman visual kepada peserta didik dalam rangka memberi motivasi untuk belajar, memperjelas materi yang diberikan, dan mempermudah konsep yang abstrak dan kompleks menjadi lebih sederhana, konkrit, dan mudah untuk dipahami.

Media juga memiliki andil dalam meningkatkan mutu dan kualitas dari proses pembelajaran. Kehadiran media tidak hanya membantu pengajar dalam menyampaikan materi ajarnya, tapi juga memberi nilai tambah pada kegiatan pembelajaran. Sejumlah kontribusi media dalam kegiatan pembelajaran yang diantaranya : penyajian materi agar menjadi lebih standar, kegiatan pembelajaran dapat berjalan lebih menarik, lebih interaktif, waktu yang dibutuhkan dalam pembelajaran dapat digunakan secara efisien, kualitas belajar dapat ditingkatkan, pembelajaran dapat disajikan dimana dan kapan saja, meningkatkan sifat positif perserta didik dan proses belajar dapat menjadi lebih baik, dan memberikan nilai positif untuk pengajar (Uno, 2011: 124).

Media pembelajaran juga berkaitan erat dengan kemajuan teknologi sebagai alat yang menunjang proses pembelajaran untuk mencapai suatu tujuan pembelajaran. Proses belajar ( learning) dengan memanfaatkan media atau bantuan alat elektronik diharapkan dapat meningkatkan efektifitas dan efisiensi dari kegiatan pembelajaran.

Michael (2013: 27) mengatakan, ELearning adalah pembelajaran yang disusun dengan tujuan menggunakan sistem elektronik atau komputer sehingga mampu mendukung proses pembelajaran. Adapun karakteristik E-Learning menurut Nursalam, (2008: 135) yaitu: (1) Memanfaatkan jasa teknologi elektronik; (2) Memanfaatkan keunggulan komputer 
(digital media dan komputer networks); (3) Menggunakan bahan ajar yang bersifat mandiri (self learning materials) kemudian disimpan di komputer, sehingga dapat diakses oleh dosen dan mahasiswa kapan saja dan dimana saja; (4) Memanfaatkan jadwal pembelajaran, kurikulum, hasil kemajuan belajar, dan hal-hal yang berkaitan dengan administrasi pendidikan dapat dilihat setiap saat di komputer.

E-Learning merupakan salah satu pembelajaran yang dapat digunakan untuk mempermudah kinerja guru dalam mengajar. E-Learning adalah pembelajaran yang paling efisien dan dekat dengan siswa. Jika media ini dikemas dengan baik, unik dan serius maka E-Learning tidak hanya sebagai media pembelajaran, tetapi juga bisa sebagai media informasi, hiburan dan pendidikan (Daryanto, 2011:168).

E-Learning dapat diartikan sebagai ilmu pembelajaran tanpa harus menggunakan kertas cetak/ hand out materi yang disampaikan. Pembelajaran dengan menggunakan E-Learning adalah cara pembelajaran yang fleksibel, karena antara pengajar dan peserta didik dapat mengakses media E-Learning tanpa terhalang waktu dan tempat untuk belajar.

Efektivitas proses belajar mengajar (pembelajaran) sangat dipengaruhi oleh faktor metode dan media pembelajaran yang digunakan. Keduanya saling berkaitan, dimana pemilihan metode tertentu akan berpengaruh terhadap jenis media yang akan digunakan, dengan kata lain bahwa harus ada kesesuaian di antara keduanya untuk mewujudkan tujuan pembelajaran (Jalinus \& Ambiyar, 2016: 4).

Pada umumnya, mahasiswa pada prodi S1 Pendidikan Teknik Bangunan FT UNJ menjalankan sistem pembelajaran terbatas hanya dikelas, sedikit mahasiswa yang melakukan pembelajaran diluar ruang kelas. Oleh sebab itu, E-Learning dapat menjadi sarana bagi mahasiwa untuk melakukan kegiatan pembelajaran di luar ruang kelas. Saat ini, prodi S1 Pendidikan Teknik Bangunan FT UNJ telah memiliki sebuah wadah E-Learning berbasis Moodle (dapat diakses melalui ptbunj.com) yang belum dimaksimalkan sepenuhnya untuk menjalankan proses pembelajaran.

Selain itu, salah satu mata kuliah yang menjadi penunjang bagi penyusunan skripsi adalah mata kuliah Metodologi Penelitian. Pada mata kuliah ini dibahas mengenai jenis-jenis penelitian, metode-metode penelitian yang akan digunakan, variable penelitian, landasan teori, hipotesis, dll. Umumnya mahasiswa kurang memiliki keterampilan untuk menuangkan idenya dalam skripsi yang dikerjakannya, ditambah lagi kurangnya tingkat literasi dan pengalamannya dalam menyusun karya ilmiah.

Berdasarkan data dari hasil analisis kebutuhan awal yang telah dilakukan, dengan responden 32 mahasiswa PTB Angkatan 2015 menunjukan bahwa 93,8\% mengusulkan adanya pembaharuan pada media pembelajaran yang digunakan dengan dikembangkannya menjadi pembelajaran ELearning, dan 84,4\% menyatakan bahwa pembelajaran yang digunakan masih menggunakan metode ceramah yang masih kurang inovatif.

Selain itu, berdasarkan data prodi mengenai catatan berita acara kegiatan seminar proposal yang telah dilakukan, dari $92 x$ pelaksanaan seminar proposal pada semester 107-109 mahasiswa pada umumnya mendapat perbaikan pada hal sebagai berikut :

Tabel 1. Presentase Kesalahan Pada Kegiatan Seminar Proposal

\begin{tabular}{|c|c|}
\hline $\begin{array}{c}\text { Hal yang perlu } \\
\text { diperbaiki }\end{array}$ & Presentase \\
\hline Judul Penelitian & $36,96 \%$ \\
\hline $\begin{array}{c}\text { Latar Belakang } \\
\text { Masalah }\end{array}$ & $98,91 \%$ \\
\hline Identifikasi Masalah & $31,52 \%$ \\
\hline Batasan Masalah & $44,57 \%$ \\
\hline Rumusan Masalah & $17,39 \%$ \\
\hline Tujuan Penelitian & $17,39 \%$ \\
\hline Manfaat Penelitian & $5,43 \%$ \\
\hline BAB 2 Penelitian & $98,91 \%$ \\
\hline BAB 3 Penelitian & $94,57 \%$ \\
\hline \multicolumn{2}{|c|}{ Tracer Studi S1 PTB ... - 3} \\
Eka MN
\end{tabular}


Berdasarkan pemaparan diatas, menarik kiranya untuk mengembangkan bahan ajar E-Learning berbasis Moodle untuk mahasiswa Prodi Pendidikan Teknik Bangunan FT UNJ dengan menggunakan tampilan media pembelajaran yang lebih menarik, ditambahkan contoh permasalahan, serta penambahan materi yang terintegrasi dengan web tertentu. Penggunaan media yang telah dikembangkan, diharapkan dapat membantu dosen pengampu untuk memudahkan proses pembelajaran yang tidak hanya dapat dilakukan dikelas saja dan terbatas waktu. Selain itu, media ajar ini juga diharapkan dapat menjadi sarana dalam membantu mahasiswa memahami materi yang disampaikan serta menjadi bekal untuk menyusun skripsi diakhir masa studi nanti.

\section{Metode Penelitian}

Pada penelitian ini, digunakan metode Penelitian dan Pengembangan atau Research and Development (R\&D). Produk yang dihasilkan nanti, tidak selalu berbentuk Perangkat Keras (Hardware), tetapi juga bisa dalam bentuk Perangkat Lunak (Software). Penelitian ini bertempat di Program Studi Pendidikan Teknik Bangunan, Fakultas Teknik, Universitas Negeri Jakarta. Berlokasi di jalan Rawamangun Muka No.1 Jakarta Timur.

Penelitian ini melibatkan mahasiswa yang telah mengambil mata kuliah Metodologi Penelitian, tepatnya yang sedang/akan menyusun skripsi pada bulan Mei 2019 - Juli 2019. Adapun Tujuan Penelitian ini adalah untuk mengembangkan suatu media pembelajaran yang berbasis ELearning untuk mata kuliah Metodologi Penelitian sesuai dengan Rencana Program Kegiatan Pembelajaran Semester (RPKPS) yang berlaku bagi mahasiswa di Program Studi Pendidikan Teknik Bangunan, Fakultas Teknik, Universitas Negeri Jakarta.

Adapun, tahapan awal dari penelitian ini adalah mengembangkan konsep atau ide yang didapat setelah melakukan identifikasi masalah melalui hasil survei analisis kebutuhan awal, yaitu penggunaan media pembelajaran yang monoton sehingga perlu adanya pembaharuan. Selanjutnya, ide tersebut dikembangkan pada tahap perancangan produk, pengumpulan bahan dan akhirnya pembuatan produk.

Selanjutnya setelah produk dibuat, akan dilakukan uji validitas produk oleh ahli media dan ahli materi. Jika setelah divalidasi produk dinilai tidak layak, maka akan kembali dilakukan tahapan perancangan produk. Bila Produk dinilai layak oleh beberapa ahli tersebut, akan dilakukan evaluasi formatif/revisi produk sesuai masukan dari ahli media dan ahli materi sebelum digunakan pada proses pembelajaran di Program Studi Pendidikan Teknik Bangunan, Fakultas Teknik, Universitas Negeri Jakarta.

Instrumen penelitian adalah sebuah alat yang digunakan untuk mengumpulkan data. Oleh sebab itu, instrumen penelitian biasanya berupa lembar check list, kuisioner/angket (baik terbuka maupun tertutup), pedoman wawancara, dll.. Pada penelitian ini, penulis menggunakan instrumen angket/kuisioner. Kuisioner adalah beberapa pertanyaan tertulis yang kemudian digunakan untuk memperoleh informasi dari responden.

Adapun, skala penilaian yang digunakan adalah Skala Likert yaitu jawaban dari setiap item yang ada memiliki gradasi dari sangat positif sampai sangat negatif. Berikut adalah skor Skala Likert yang digunakan oleh peneliti :

Tabel 2. Skala Likert

\begin{tabular}{|c|c|}
\hline Pilihan & Skor \\
\hline Sangat Tidak Setuju & 1 \\
\hline Tidak Setuju & 2 \\
\hline Ragu-Ragu & 3 \\
\hline Setuju & 4 \\
\hline Sangat Setuju & 5 \\
\hline
\end{tabular}

Kisi-kisi instrumen yang digunakan, adalah adaptasi dari kisi-kisi instrumen yang dikembangkan oleh Estu Miyarso (2004: 
19). Alasan peneliti memilih instrumen tersebut, karena kisi-kisi intrumen yang dikembangkan merupakan mengembangkan pembelajaran E-Learning berbasis multimedia. Sesuai dengan media ELearning yang akan dikembangkan. Kisi-kisi instumen mencakup beberapa komponen, antara lain: (1) Kisi-kisi instrumen untuk Ahli materi terdiri dari aspek pembelajaran dan aspek materi, yang berjumlah 10 indikator; (2) Kisi-Kisi instrumen untuk ahli media terdiri dari aspek tampilan dan aspek pemrograman, yang berjumlah 25 indikator.

Pada penelitian ini, digunakan teknik pengumpulan data dengan cara kuisioner. Dimana angket yang telah divalidasi oleh dosen pembimbing berupa penilaian semua aspek yang ada dalam media pembelajaran, kemudian diberikan kepada ahli media dan ahli materi. Pemberian angket dilakukan pada langkah validasi ahli materi dan ahli media.

Teknik analisis data adalah memproses angka-angka yang telah didapat dari hasil pengukuran data angket untuk digunakan sebagai penilaian dari ahli materi dan ahli media. Selanjutnya, data yang telah diperoleh dianalisis untuk mengetahui kelayakan media yang telah dibuat. Data yang diperoleh berupa data kualitatif. Data kualitatif yang dimaksud adalah penilaian, kritik, dan saran dari para ahli media dan ahli materi. Pada penelitian ini, digunakan teknik analisis data sebagai yaitu, analisis validasi oleh ahli dilakukan dengan menggunakan Skala Likert. Jawaban setiap item instrumen yang menggunakan skala Likert mempunyai gradasi dari sangat positif sampai sangat negatif. Skor penilaian yang digunakan adalah 1 sampai 5, dimana 1 sebagai nilai terendah dan 5 sebagai nilai tertinggi. Rumus untuk menghitung nilai persentase skor adalah sebagai berikut: dalam bentuk persentase tersebut dengan tabel interpretasi skor kelayakan sebagai berikut :

Tabel 3. Interpretasi Skor Kelayakan

\begin{tabular}{|c|c|}
\hline Presentase (\%) & Kriteria \\
\hline $0-20$ & Sangat Tidak Layak \\
\hline $21-40$ & Tidak Layak \\
\hline $41-60$ & Cukup Layak \\
\hline $61-80$ & Layak \\
\hline $81-90$ & Sangat Layak \\
\hline
\end{tabular}

\section{Hasil Penelitian dan Pembahasan}

Produk E-Learning yang dihasilkan pada penelitian ini berupa beberapa materi yang disebut Courses yang disusun sesuai dengan Rencana Program Kegiatan Pembelajaran Semester (RPKPS) mata kuliah metodologi penelitian. Produk E-Learning ini dapat diakses melalui website milik program studi S1 Pendidikan Teknik Bangunan FT UNJ yaitu ptbunj.com. Media Pembelajaran yang dihasilkan dibuat dengan bantuan aplikasi Powerpoint sebagai pengolah materi, Googleslides sebagai penyunting file materi yang dibuat, dan Moodle sebagai sarana ELearning yang akan digunakan pada kegiatan pembelajaran.

Untuk mendapatkan hasil pengembangan produk bahan ajar yang baik dan sesuai dengan standar, maka dilakukan validasi produk pengembangan bahan ajar E-Learning mata kuliah metodologi penelitian oleh 2 ahli materi dan 2 ahli media sebagai validator dengan menggunakan kuisioner. Validasi oleh ahli materi dan ahli media menggunakan skala Likert yang memiliki 5 tingkatan jawaban.

Berikut adalah contoh tampilan ELearning pada Moodle yang telah dikembangkan :

\footnotetext{
Presentase $=\frac{\text { Skor yang diobseryasi }}{\text { Skor yang dikarapkan }} \times 100 \%$

Adapun kriteria kelayakan yang dapat dikategorikan dari data yang diperoleh
} 
Gambar 1. Tampilan E-Learning pada Moodle

Berdasarkan validasi yang telah dilakukan, berikut adalah hasil akhir validasi dari 2 ahli media dan 2 ahli materi :

Tabel 4. Hasil Akhir Penilaian Ahli Materi dan Ahli Media

\begin{tabular}{|c|c|c|c|}
\hline & $\begin{array}{c}\text { Validator } \\
1\end{array}$ & $\begin{array}{c}\text { Validator } \\
2\end{array}$ & $\begin{array}{c}\text { Skor } \\
\text { Akhir }\end{array}$ \\
\hline $\begin{array}{c}\text { Ahli } \\
\text { Materi }\end{array}$ & $80,18 \%$ & $82,91 \%$ & $81,54 \%$ \\
\hline $\begin{array}{c}\text { Ahli } \\
\text { Media }\end{array}$ & $84 \%$ & $72,8 \%$ & $78,4 \%$ \\
\hline
\end{tabular}

Berdasarkan tabel diatas, hasil dari validasi ahli materi mendapat skor akhir $81,54 \%$ yang termasuk kategori sangat layak, serta hasil validasi ahli media mendapat skor akhir 78,4\% yang termasuk kategori layak.

Adapun saran yang diberikan oleh ahli materi setelah di validasi, antara lain: (1) Periksa kesesuaian materi; (2) Tuliskan sumber referensi; (3) Ditambahkan cara penggunaan nomogram Harry King.

Saran yang diberikan oleh ahli media setelah divalidasi, antara lain: (1) Perlunya ditambahkanpetunjukpenggunaan/Learning Guide; (2) Grafis dekoratif yang tidak sesuai dengan konten diminimalisir; (3)Berikan informasi tentang mata kuliah di RPKPS; (4) Berikan deskripsi tentang materi; (5) Dibuat per topik materi menjadi per tab.

\section{Simpulan}

Berdasarkan hasil penelitian yang telah dilakukan pada pengembangan media pembelajaran E-Learning mulai dari kegiatan menentukan latar belakang masalah, analisis kebutuhan awal, penentuan produk serta spesifikasi yang akan digunakan, perancangan produk, pengembangan produk, sampai revisi produk dapat disimpulkan bahwa hasil pengembangan media pembelajaran ELearning pada mata kuliah Metodologi Penelitian dapat digunakan sebagai salah satu opsi media pembelajaran yang dapat digunakan pada kegiatan pembelajaran mata kuliah Metodologi Penelitian. Hasil kelayakan dengan total 11 Modul yang disajikan dalam media pembelajaran ELearning adalah sebagai berikut : a) Penilaian oleh ahli media mendapatkan nilai sebesar 78,4\% yang termasuk kategori layak ; dan b) Penilaian oleh ahli materi yang mendapatkan nilai sebesar $81,54 \%$ yang termasuk kategori sangat layak. Dari hasil kelayakan ini, dapat ditarik kesimpulan bahwa media pembelajaran E-Learning yang dikembangkan layak digunakan sebagai variasi media pembelajaran mata kuliah Metodologi Penelitian.

Berdasarkan hasil penelitian dan pengembangan media pembelajaran ELearning berbasis Moodle ini, maka penulis memberikan saran sebagai berikut: (1) Produk pengembangan media pembelajaran ini dapat digunakan sebagai variasi dalam pembelajaran mata kuliah Metodologi Penelitian dengan menggunakan akses internet yang memadai; (2) Penelitian dapat dilanjutkan dengan mengambil tema mengenai efektifitas penggunaan media pembelajaran E-Learning berbasis Moodle pada mata kuliah Metodologi Penelitian; (3) Dengan adanya fasilitas pembelajaran berupa E-Learning pada prodi S1 Pendidikan Teknik Bangunan FT UNJ, diharapkan dapat dimaksimalkan dengan sebaik mungkin kedepannya.

\section{Daftar Pustaka}

Arsyad, Azhar. (2006). Media Pembelajaran. Jakarta: Rajawali Pers

Daryanto. (2011). Media Pembelajaran. Yogyakarta: Gaya Media.

Jalinus, N., \& Ambiyar. (2016). Media dan Sumber Pembelajaran (Pertama). Jakarta: Kencana

Komsiyah, Indah.(2012). Belajar Dan Pembelajaran. Yogyakarta: Teras. 
Riadi, Muchlisin. (2014). Pengertian, Karakteristik dan Manfaat E-Learning Diakses pada 13 Mei 2019 pukul 08.52 WIB,https://www.kajianpustaka.com/2 014/06/pengertian-karaktiristikdanmanfaat-elearning.html

Sadiman, Arief S. (2009). Media Pengajaran Pengertian, Pengembangan, Dan Pemanfaatannya. Jakarta: PT. Raja Grafindo Persada.

Sardiman, Arief. (2010). Media Pendidikan. Jakarta: PT. Raja Grafindo Persada.

Sodikin. (2009). Jurnal Penyesuaian Dengan Modus Pembelajaran Untuk Siswa SMK Kelas X. Jurnal Teknologi Informasi 5

Sugiyono, P. D. (2015). Metode Penelitian dan Pengembangan. Bandung: ALFABETA.

Uno, Hamzah B. (2011). Tekhnologi Komunikasi Dan Informasi Pembelajaran. Jakarta: Bumi Aksara. 